\title{
Assessment of Environmental Sources, Levels and Distribution of Polycyclic Aromatic Hydrocarbons within Nzoia Catchment Area in Kenya
}

\author{
Agripina Shitandayi $^{{ }^{*}}{ }^{(0)}$, Francis Orata ${ }^{1,2}$, Fred Lisouza ${ }^{1}$ \\ ${ }^{1}$ Department of Pure and Applied Chemistry, Masinde Muliro University of Science and Technology, Kakamega, Kenya \\ ${ }^{2}$ Centre of Excellence in Water Resource Management (CEWARM), Masinde Muliro University of Science and Technology, \\ Kakamega, Kenya \\ Email: *ashitandayi@Mmust.ac.ke
}

How to cite this paper: Shitandayi, A., Orata, F. and Lisouza, F. (2019) Assessment of Environmental Sources, Levels and Distribution of Polycyclic Aromatic Hydrocarbons within Nzoia Catchment Area in Kenya. Journal of Environmental Protection, 10, 772-790.

https://doi.org/10.4236/jep.2019.106046

Received: April 25, 2019

Accepted: June 18, 2019

Published: June 21, 2019

Copyright $\odot 2019$ by author(s) and Scientific Research Publishing Inc. This work is licensed under the Creative Commons Attribution International License (CC BY 4.0).

http://creativecommons.org/licenses/by/4.0/

\section{(c) (i) Open Access}

\begin{abstract}
Continuous concerns about Polycyclic Aromatic Hydrocarbons (PAHs) presence in the environment have raised concern because of their toxic effects to various organisms. Sugarcane farming and cane processing industries are major economic activities within River Nzoia catchment area in Kenya. For instance, the sugar industries produce wastes and by products which can cause PAHs emission and environmental contamination in addition to activities related to rapid urbanization that is being observed within the catchment. This study presents a report on sources and distribution of PAHs levels in sugarcane by products waste, sediments, water and soils within the River Nzoia catchment area. Soil and sediment samples were extracted by soxhlet extraction using dichloromethane and with C-18 catridges. Analyte separation and identification was done by GC-MS. Fourteen PAHs were detected with concentration ranges of; $0.6 \mu \mathrm{g} / \mathrm{L}-80 \mu \mathrm{g} / \mathrm{L}$ for water, $0.01 \mu \mathrm{g} / \mathrm{kg}-1200$ $\mu \mathrm{g} / \mathrm{kg}$ for soils and $0.13 \mu \mathrm{g} / \mathrm{kg}-19.6 \mu \mathrm{g} / \mathrm{kg}$ for sediments. Bagasse waste had PAHs concentrations in the range of $0.4-14 \mu \mathrm{g} / \mathrm{kg}$, and filter cake in the range of $1.7-30 \mu \mathrm{g} / \mathrm{kg}$. Boiler waters reported the presence of 8 PAHs. The ratio of concentrations of PAHs in boiler water, filter cake and bagasse waste to the soils and water samples within the vicinity to the sugar processing companies did not indicate a point source of contamination; rather it pointed to diffuse sources. The same results were observed for water and sediment samples obtained in the vicinity of waste dumpsite. Variation of PAHs concentrations from sugar manufacturing processes corresponded to the kind and conditions of the processes. Lower molecular weight PAHs dominated in
\end{abstract}


water sample. The presense of benz: 1) pyrene, benz 2) flourancene and Indeno(123,cd)pyrene in both water and sludge soils are of concern since this water is abstracted for domestic use, while sludge soil is used as fertilizer in agricultural farms. Although the levels of PAHs obtained in this study were below the established environment and human health safefty limits, the results underscore the need for mornitoring levels and determining potential sources for PAHs in the environment.

\section{Keywords}

Polycyclic Aromatic Hydrocarbons, Sugarcane by Products, Sources and Distribution, Waste Disposal

\section{Introduction}

The term polycyclic aromatic hydrocarbons (PAHs) refers to organic chemical compounds that consist of two or more fused aromatic rings and do not contain heteroatom or carry substituents [1]. PAHs are regarded as environmental pollutants [2] [3] that are formed mainly due to incomplete combustion of waste [4] [5]. Other anthropogenic sources of PAHs include vehicle exhaust, coal combustion for cooking and heating, industrial effluent, domestic effluent and municipal waste incineration among others [6]. The United States environmental protection agency (US EPA) prioritised sixteen PAHs of which, those with high molecular weight PAHs are of concern because they have been identified as potential carcinogens [7], mutagens and teratogens [8]. Therefore, there is need to ascertain the sources and distribution of PAHs in places where there is potential of occurrence and contamination in industrial processes such as in sugarcane production and processing [9]. Studies in Brazil reported the presence of benzo[a]anthracene $(\mathrm{BaA})$, benzo[a]pyrene $(\mathrm{BaP})$, and dibenzo[a,h]anthracene (DBA) among other PAHs in cachacüa, (a Brazilian sugar cane spirit), where it was observed that samples produced from burned sugar cane fields had higher $\mathrm{PAH}$ levels than those produced from non-burned sugar cane [10]. Therefore sugarcane burning was found to be a source of PAHs. Sugar cane by products such as filter mud, bagasse, boiler water and molasses [11], may contain PAHs. Nzoia catchment area is the main sugar belt region of Kenya. The catchment is a home for sugar industries, for instance Mumias, Butali, West Kenya and Nzoia sugar companies. There is need to assess the levels, sources and distribution of PAHs among the by products of these sugarcane industries, and also their distribution in sediments, water and soils within the region. It is expected that the agricultural soils around the sugar factories and urban areas in the study region will have higher concentrations of PAHs than the ones further away from these areas.

Sediments act as a sink for PAHs [12], which may originate from urban centres [13]. Lack of sufficient data on PAHs pollution in soil, river water and sedi- 
ments environmental pollutants is an obstacle to put in place mitigative measures for controlling PAHs pollution, hence the need for this study. Levels sources, distribution, occurrence, transport, and fate of PAHs have been documented in various matrices samples [14] [15] [16] and compared in both the urban areas rather than those of rural areas [17] [18]. In Kenya, levels of PAHs in water and sediments [19] [20] [21] [22] [23], burning fuel biomass [24], urban air [5] have been previously reported. PAHs analysed in soil, water, sediments and other matrices can provide important information on the state of environmental pollution and the concentrations of individual PAHs in soil resulting mainly from motor vehicle exhaust that usually ranges between 1 and 2000 $\mu \mathrm{g} / \mathrm{kg}$ [25]. This study was carried out in order to assess the PAHs environmental levels and their occurance in sugar production process waste, as well as determine their Distribution within Nzoia Catchment Area.

\section{Materials and Methods}

\subsection{Study Area}

This study was conducted in the sugar belt regions of the Nzoia River catchment area of Kenya. River Nzoia Catchment lies between latitudes $1^{\circ} 30^{\prime} \mathrm{N}$ and $0^{\circ} 05^{\prime} \mathrm{S}$ and longitudes $34^{\circ}$ and $35^{\circ} 45^{\prime} \mathrm{E}$ as shown in Figure 1. One of its major tributaries of the River Nzoia is River Isiukhu. The sampling locations within Nzoia River Catchment were selected depending on the social-economic activities and waste generation and disposal methods within the study location. The specific sampling locations were; Shirere, Rostaman, Mwibatsiro, Rostamandumpsite, Mmust dumpsite, Shirere, Shibeye, Ekero, West Kenya sugar company, Nzoia sugar company, Mumias sugar company and within Kakamega Municipality. Soil samples were collected from Mumias farm, Mumias nuclear estate. Sludge soil was collected from the Municipal dumpsite and Mmust dumpsite. Sediment and water samples were collected from Mumias sugar company stream, at Ekero, Shibeye and Rosterman all along Isiukhu river, Mwibatsiro and MMUST stream. Within the sugar company, the by products as waste from the sugar production proceses sampled for analysis were; Baggasse waste from Nzoia Sugar Company (NSC), Baggasse waste from West Kenya Sugar Company (WKSC), Filter cake WKSC, Filter cake NSC, Boiler water NSC and Boiler water WKSC. Table 1 describes the area where samples were collected.

The selection of these points was based upon human activities taking place near the river banks such as sand harvesting, farming, waste and effluents disposal methods and accessibility. The area surrounding the sampling sites had sugarcane farming as the main economic activity. The sampling sites, rivers, and the forest within the study area are shown in Figure 1.

\subsection{Chemicals and Apparatus}

High purity standard for PAHs was purchased from Sigma Aldrich, UK. Solid Phase Extraction cartridges and nylon micro filters were purchased from Merck 


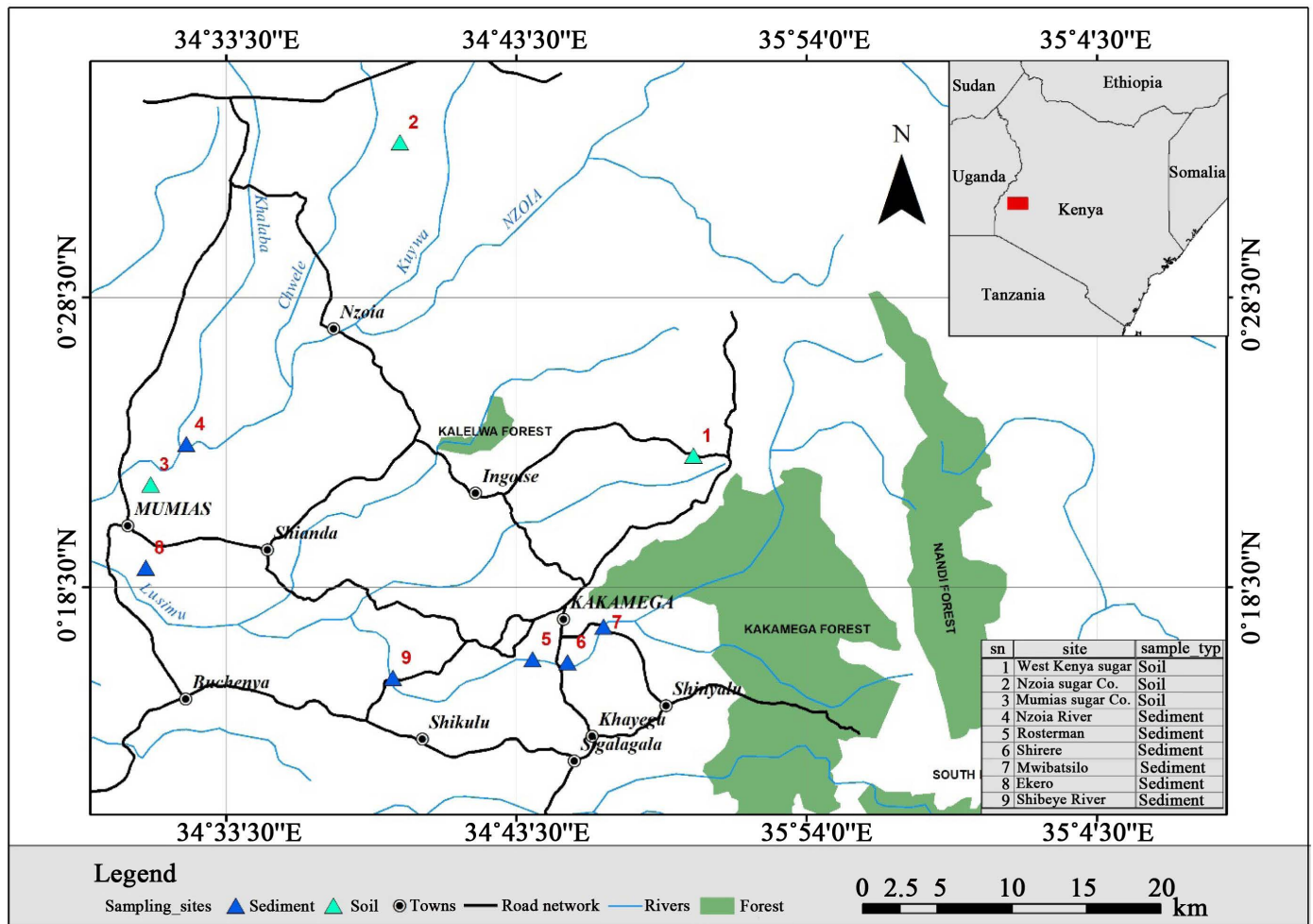

Figure 1. Map of River Nzoia catchment area showing the study locations (numbered 1 to 13). WKSC (1), NSC (2), Mumias sugar company stream (3), Mumias Nuclear Estate (4), Rosterman (5), Shirere (6), Mwibatsiro (7), Ekero (8), Shibeye (9), MMUST (10), Municipal dumpsite (11), MMUST stream (12), Municipal sludge soil (13).

Table 1. Description and coordinates of sampling locations.

\begin{tabular}{|c|c|c|c|}
\hline Sampling site & Type of sample & Coordinates of the site & Location description \\
\hline Shirere & Sediment and water & $34^{\circ} 44^{\prime} 30^{\prime \prime} \mathrm{E} 0^{\circ} 28^{\prime} 30^{\prime \prime} \mathrm{N}$ & Sand harvesting and farming along the river. \\
\hline Rostaman & Sediment and water & $34^{\circ} 43^{\prime} 30^{\prime \prime} \mathrm{E} 0^{\circ} 18^{\prime} \mathrm{N}$ & $\begin{array}{l}\text { Gold mining, informal settlements, illegal wastes } \\
\text { and discharges damping site due to mining activity } \\
\text { and maize farming along the river banks. }\end{array}$ \\
\hline Mwibatsiro stream & Sediment and water & $34^{\circ} 54^{\prime} 0^{\prime \prime} \mathrm{E} 0^{\circ} 18^{\prime} \mathrm{N}$ & Maize and Napier grass farming along the river \\
\hline Municipal dumpsite & Soil & $34^{\circ} 53^{\prime} 20^{\prime \prime} \mathrm{E} 0^{\circ} 28^{\prime} 30^{\prime \prime} \mathrm{N}$ & $\begin{array}{l}\text { Kakamega town damping site; industrial, } \\
\text { agricultural and domestic wastes from the town } \\
\text { and the neighborhood localities. }\end{array}$ \\
\hline Shirere sewage & Soil, sediments and water & $34^{\circ} 45^{\prime} 0^{\prime \prime} \mathrm{E} 0^{\circ} 28^{\prime} 30^{\prime \prime} \mathrm{N}$ & Sand harvesting and maize farming along the river. \\
\hline Ekero & Sediments and water & $34^{\circ} 33^{\prime} 0^{\prime \prime} \mathrm{E} 0^{\circ} 28^{\prime} 30^{\prime \prime} \mathrm{N}$ & Sugarcane farming, and maize farming. \\
\hline MMUST damp site & Soil & $34^{\circ} 29^{\prime} 20^{\prime \prime} \mathrm{E} 0^{\circ} 18^{\prime} \mathrm{N}$ & $\begin{array}{l}\text { Main MMUST dumpsite, kitchen wastes and } \\
\text { domestic wastes. }\end{array}$ \\
\hline Mayoni & Sediment and water & $34^{\circ} 43^{\prime} 28^{\prime \prime} \mathrm{E} 0^{\circ} 18^{\prime} \mathrm{N}$ & $\begin{array}{l}\text { Sugarcane farming, sand harvesting and } \\
\text { car wash along the river banks. }\end{array}$ \\
\hline Shibeye & Sediments and water & $34^{\circ} 33^{\prime} 20^{\prime \prime} \mathrm{E} 0^{\circ} 28^{\prime} 30^{\prime \prime} \mathrm{N}$ & Sugar cane farming. \\
\hline West Kenya sugar Company & Boiler water and mud filter & $35^{\circ} 4^{\prime} 30^{\prime \prime} \mathrm{E} 0^{\circ} 18^{\prime} \mathrm{N}$ & $\begin{array}{l}\text { Sugar processing, accumulation and transportation } \\
\text { of mud filter to various farms. }\end{array}$ \\
\hline Mumias sugar Company & $\begin{array}{l}\text { Burnt farm soil and } \\
\text { nuclear estate soil }\end{array}$ & $34^{\circ} 32^{\prime} 20^{\prime \prime} 0^{\circ} 18^{\prime} \mathrm{N}$ & $\begin{array}{l}\text { Sugar processing, accumulation and transportation } \\
\text { of mud filter to various farms. }\end{array}$ \\
\hline Nzoia sugar Company & $\begin{array}{l}\text { Bagasse soil, mud filter } \\
\text { and boiler water }\end{array}$ & $34^{\circ} 46^{\prime} 30^{\prime \prime} 0^{\circ} 28^{\prime} \mathrm{N}$ & $\begin{array}{l}\text { Sugar processing, accumulation and transportation } \\
\text { of mud filter to various farms. }\end{array}$ \\
\hline
\end{tabular}


Chemicals. Anhydrous Sodium sulfate $\left(\mathrm{Na}_{2} \mathrm{SO}_{4}\right)$, Dichloromethane and Iso-octane were of analytical grade reagent purchased from Kobian Chemicals Nairobi. Internal standard dodecane was purchased from Sigma Aldrich, UK and Reference standards of PAHS obtained from IoIc (Warsaw: Puder, Poland). Soxhlet extraction apparatus, SPE cartridges, $0.45 \mu \mathrm{m}$ PTFE (polytetrafluoroethylene) syringe filter, cellulose extraction thimble, from Kobian Chemicals Nairobi and GC-MS instruments with the following specifications: GC Model of 7890A manufactured by Agilent technologies, Inc, Beijing China, with a MASS detector of 5973C by Agilent Technologies, Inc. Santa Clara, CA, USA attached to an auto sampler of 7683 by Agilent Technologies.

\subsection{Sampling}

Reconnaissance study was done to obtain information regarding the locations where sampling was done, based on the activities that take place within the locations (see Table 1). Sample was collected from sites believed to have previous history of anthropogenic activities that include open burning or combustion such as dump sites, sugarcane fields, urban areas, rivers in the vicinity of sugar factories, and also in sites that have no history of interferences by anthropogenic activities such as Kakamega forest, for comparison. Control samples were obtained within the Kakamega forest. Sediment sample was collected using an Ekman Grabber. Water sample was collected in amber bottles and soil samples were collected using a stainless steel hoe and scooped using stainless steel shovel. The samples were then wrapped in clean piece of aluminum foil, packed in black polythene bag, and labeled. The entire sample was placed in cooler boxes and transported to the university laboratory where they were stored in the refrigerator at $4^{\circ} \mathrm{C}$.

\subsection{Water Sample Extraction and Analysis}

Extraction of water samples was done by solid phase extraction procedure which was adopted from US EPA Method 3510C [26]. $500 \mathrm{mls}$ of water sample was measured using a glass measuring cylinder, transferred into a $1.0 \mathrm{~L}$ beaker and its $\mathrm{pH}$ recorded. The water sample was filtered using what man filter paper No.1 to remove other impurities. The $\mathrm{pH}$ was adjusted by adding drops of $0.1 \mathrm{M}$ hydrochloric acid or $0.1 \mathrm{M}$ sodium hydroxide solutions with carefully stirring to adjust the $\mathrm{pH}$ to 7.0. The neutral solution was transferred to $500 \mathrm{ml}$ beaker and treated with $25 \mathrm{~g}$ of sodium chloride to salt out the PAHs from aqueous phase to organic phase. The mixture was further shaken gently and allowed to settle for 30 minutes to enhance homogeneity. Extraction process was repeated thrice each time with $30 \mathrm{ml}$ dichloromethane. The combined extracts were dried using activated anhydrous $\mathrm{Na}_{2} \mathrm{SO}_{4} .2 \mathrm{ml}$ of isooctane was added as keeper of the PAHs then concentrated to about $2 \mathrm{ml}$. The concentrated extracts were filtered with $0.45 \mu \mathrm{m}$ PTFE (polytetrafluoroethylene) syringe filter, and the volume adjusted to the $2 \mathrm{mls}$ mark using the mobile phase solvent before the extract was stored in 
a fridge at $-4^{\circ} \mathrm{C}$ prior to GC-MS analysis [27]. Dodecane was used as the internal standard.

\subsection{Sediment and Soil Samples Extraction and Analysis}

Sediment samples were removed from freezer and allowed to thaw for about 4 hours prior to extraction. Samples were air-dried in the dark, crushed and sieved with a $2 \mathrm{~mm}$ sieve. About 10 grams of the sieved samples were weight and put into the Soxhlet extraction thimble and 0.1 of $0.01 \mu \mathrm{l} / \mathrm{ml}$ dodecane solution added as the internal standard. This was extracted with $250 \mathrm{ml}$ of dichloromethane in a round bottomed flask for at least 8 hours in a Soxhlet extractor set-up. The extracts were dried using $2 \mathrm{~g}$ of anhydrous sodium sulphate. $2 \mathrm{ml}$ of isooctane was added as keeper, and the mixture concentrated to $2 \mathrm{ml}$. The concentrated extracts were filtered through a $0.45 \mu \mathrm{m}$ PTFE (polytetrafluoroethylene) syringe filter, stored in a fridge at $-4^{\circ} \mathrm{C}$ prior to GC-MS analysis.

\subsection{Instrumental Sample Analysis}

The samples were run using GC-MS: GC Model of 7890A hyphenated with a MASS detector of $5973 \mathrm{C}$ by Agilent Technologies, Inc. Santa Clara, CA, and USA attached to an auto sampler of 7683 by Agilent Technologies. The GC was equipped with a DB-5 silica fused high performance capillary column, $(30 \mathrm{~m}$ length, $0.25 \mathrm{~mm}$ internal diameter and $0.25 \mu \mathrm{m}$ film thickness). The carrier gas was helium (99.99\%) with a constant flow rate of $2 \mathrm{ml} / \mathrm{min}$. Make up gas was (99.99\%) with a constant flow rate of $2 \mathrm{ml} / \mathrm{min}$. The injection volume was $1 \mu \mathrm{l}$ with a pulsed split less injection mode. The oven temperature was started initially at $80^{\circ} \mathrm{C}$ where it was held for 3 mins. Programmed for two temperature ramps was from $80^{\circ} \mathrm{C}$ to $280^{\circ} \mathrm{C}$ with increase at $10^{\circ} \mathrm{C} \cdot \mathrm{min}^{-1}$ and held for 20 mins. Injector temperatures were 250 and detector temparature was $300^{\circ} \mathrm{C}$. Solvent delay was programmed at 5 mins. The mass selective detector was operated in the electron ionization $(70 \mathrm{eV})$ and the selected ion monitoring modes. Mass range was between m/z 30 - 450. Samples for GC-MS analysis were evaporated to dryness under reduced pressure and residue re-dissolved in $50 \mu \mathrm{L}$ of iso-octane. Analysis by GC-MS was performed in split/splitles mode. Mass spectrometry was operated on electron impact ionization mode. Analyte identification was also based on the comparison of mass spectra of unknowns with those in the NIST/EPA/NIH MASS SPECTRAL LIBRARY library [28]. Quantitative analysis of PAHs was achieved through the integration of selected GC chromatograms.

\subsection{Analytical Quality Control}

Extraction efficiency was tested by obtaining recovery values. Five blank samples which were prepared in the same way that the real analytical samples were prepared were used for each set of ten real analytical samples analysed. Calibration curves were drawn for all the elements to be analyzed and regression equations 
determined for every calibration curve, to check the instrumental response to various analyte concentrations. In all the cases regression was found have $\mathrm{r}^{2}=$ 0.99 and above. Accuracy and precision of the method were also tested.

\section{Results and Discussion}

Analytical quality control included determination of compound-specific estimating instrument detection limits (IDL) and method detection limits (MDL) and the calculation of internal standard recoveries. Recovery values were obtained by spiking each matrix with internal standard and ranged from $61.23 \%$ to $72.89 \%$. There were no detected PAHs in the blank samples. The IDL was set at a signal to noise ratio of 3 , as obtained from the chromatograms and the MDL was defined as the mean concentration of the compounds plus 3 times the standard deviation of signals obtained from the procedural blank experiments. The IDL and the MDL are shown in Table 2. Control samples were obtained from stream and soil within, deep in the Kakamega tropical rain forest. The concentrations obtained from the water control samples were $0.06 \mu \mathrm{g} / \mathrm{L}$ for naphthalene and $1.10 \mu \mathrm{g} / \mathrm{L}$ for pyrene. The other PAHs gave concentarion values below the MDL. Concentrations obtained from the control soil sample were $1.1 \mu \mathrm{g} / \mathrm{kg}$ for anthracene and $0.08 \mu \mathrm{g} / \mathrm{kg}$. Other PAHs in control soil samples had their concentrations $\geq$ MDL. The linearity response obtained from the calibration standard as shown in Table 2 and was found to be good. Accuracy and precision of analyses were found to be satisfactory. Table 2 also shows the molecular ion that was used to identify the PAHs in the chromatograms.

Table 2. PAHs analyzed showing the $\mathrm{m} / \mathrm{z}$ monitored, the standard linearity response $\mathrm{r}^{2}$ values, the percentage (\%) recoveries and the IDL and MDL set values.

\begin{tabular}{|c|c|c|c|c|c|c|}
\hline $\begin{array}{c}\text { Peak } \\
\text { no. }\end{array}$ & PAHs & $\mathrm{m} / \mathrm{z}$ & $\begin{array}{l}\text { Correl. Coeff. } \\
\left(\mathrm{r}^{2}\right)\end{array}$ & $\begin{array}{c}\text { Recovery } \\
(\%)\end{array}$ & IDL & MDL \\
\hline 1 & Naphthalene (Nap) & $128 / 130$ & 0.9953 & 72.89 & 0.02 & 0.06 \\
\hline 2 & Acenaphthylene (Acy) & $152 / 154$ & 0.9953 & 70.64 & 0.02 & 0.5 \\
\hline 3 & Acenaphthene (Ace) & $153 / 154$ & 0.9968 & 64.73 & 0.02 & 1.0 \\
\hline 4 & Fluorene (Flu) & $166 / 168$ & 0.9965 & 71.12 & 0.2 & 0.5 \\
\hline 5 & Phenanthrene (Phe) & $176 / 178$ & 0.9985 & 61.62 & 0.2 & 1.0 \\
\hline 6 & Anthracene (Ant) & $176 / 178$ & 0.9956 & 71.25 & 0.05 & 0.5 \\
\hline 7 & Flourancene (Flr) & $200 / 202$ & 0.9974 & 72.64 & 0.2 & 1.0 \\
\hline 8 & Pyrene (Pyr) & $200 / 202$ & 0.9968 & 64.94 & 0.05 & 1.0 \\
\hline 9 & $\operatorname{Benz}(\mathrm{a})$ anthracene $(\mathrm{BaA})$ & $226 / 228$ & 0.9964 & 71.34 & 0.05 & 1.0 \\
\hline 10 & Chrysene (Chr) & $226 / 228$ & 0.9962 & 62.61 & 0.05 & 0.2 \\
\hline 11 & Benz(b)flourancene $(\mathrm{BbF})$ & $250 / 252$ & 0.9960 & 70.64 & 0.05 & 0.1 \\
\hline 12 & $\operatorname{Benz}(\mathrm{a})$ pyrene $(\mathrm{BaP})$ & $250 / 252$ & 0.9943 & 61.84 & 0.05 & 0.2 \\
\hline 13 & Indeno( $123, \mathrm{~cd})$ pyrene (InP) & $276 / 278$ & 0.9960 & 61.23 & 0.05 & 0.1 \\
\hline 14 & Dibenzo(def,mno)chrysene (DBC) & $276 / 278$ & 0.9979 & 64.78 & 0.05 & 0.1 \\
\hline
\end{tabular}


Detection of PAHs varied from one sampling point to another. For example, fluorene (Flu) and chrysene (Chr), were not detected in all the sampling locations within the sugarbelt region, while naphthalene (Nap) was detected in almost all samples analysed. The results of the concentration of PAHs obtained for water, soil and sediment samples are shown in Table 3. Kakamega municipal dumpsite samples had the highest concentration obtained for Nap, $160 \mu \mathrm{g} / \mathrm{kg}$ and for Anthracene (Ant) $1200 \mu \mathrm{g} / \mathrm{kg}$. The results obtained at the Kakamega municipal dumpsite were different to those obtained at MMUST dumpsite where the concentration of Nap was $6.0 \mu \mathrm{g} / \mathrm{kg}$. The difference in the amount of waste between the two dumpsites could be the probable reason to explan the difference. While Kakamega dumpsite services a population of about half a million people, the MMUST dumpsite is community owned and services about five thousand people. Concentrations of acenaphthene (Ace), flourancene (Flr), chrysene (Chr) and Dibenzo(def,mno)chrysene (DBC) were below MDL. It was interesting to note that samples of municipal sludge soils had concentrations of $3.80 \mu \mathrm{g} / \mathrm{kg}$ for Ant, $8.0 \mu \mathrm{g} / \mathrm{kg}$ for Pyrene(Pyr), $1.72 \mu \mathrm{g} / \mathrm{kg}$ for Benz(a)pyrene $(\mathrm{BaP})$ and $1.12 \mu \mathrm{g} / \mathrm{kg}$ for Indeno(123,cd)pyrene (InP). The addition of sewage sludge to agricultural soils can be a source of PAHs in these soils. PAHs concentrationis proportional to the amount of sewage sludge applied to agricultural field soils [29]. This is interesting considering that sewage sludge is often used as fertilizer.

Table 3. Concentrations of the 16 priority PAHs in different matrices in different sampling sites (Soils: $\mu \mathrm{g} / \mathrm{kg}$ and Water: $\mu \mathrm{g} / \mathrm{L}$ ).

\begin{tabular}{|c|c|c|c|c|c|c|c|c|c|c|c|c|c|c|c|}
\hline Matrices & Sampling location & Nap & Acy & Ace & Flu & Phe & Ant & Flr & Pyr & $\mathrm{BaA}$ & Chr & $\mathrm{BbF}$ & $\mathrm{BaP}$ & InP & DBC \\
\hline \multirow{5}{*}{ Soil } & Mumias farm & 1.32 & 0.60 & - & 0.80 & 6.00 & - & - & - & 3.4 & - & - & - & - & - \\
\hline & Mumias nuclear estate & 1.50 & 0.80 & - & 0.88 & 6.0 & 20 & - & - & - & - & - & - & - & - \\
\hline & $\begin{array}{c}\text { Kakamega municipal } \\
\text { dumpsite }\end{array}$ & 160.0 & - & - & - & - & 1200 & - & - & - & - & 10 & - & - & - \\
\hline & Municipal sludge soil & - & - & - & - & - & 3.8 & - & 8.0 & - & - & - & 1.72 & 1.12 & - \\
\hline & MMUST dumpsite & 6.0 & - & - & - & - & - & - & - & - & - & - & - & 4.0 & - \\
\hline \multirow{6}{*}{ Sediment } & Mumias sugar Co. stream & 6.0 & - & - & 5.0 & - & - & - & - & - & 1.20 & 2.0 & - & - & 4.0. \\
\hline & Ekero & 32.0 & - & - & 14 & - & 80.0 & - & - & - & - & 4.0 & - & - & - \\
\hline & Shibeye & 4.50 & - & - & 0.94 & - & 40.0 & - & - & - & - & - & - & - & - \\
\hline & Rosterman & - & - & - & - & - & - & - & - & - & - & 1.14 & - & - & 0.14 \\
\hline & Mwibatsiro & 19.60 & - & - & 5.2 & - & 6.0 & - & - & - & - & - & - & - & - \\
\hline & MMUST stream & - & - & - & - & - & - & - & - & - & - & 0.14 & - & 0.12 & - \\
\hline \multirow{6}{*}{ Water } & Mumias sugar Co. stream & 15.60 & - & - & - & - & - & - & - & - & - & - & 5.2 & - & - \\
\hline & Ekero & 0.12 & 3.60 & - & - & - & - & - & 3.16 & - & - & - & - & - & - \\
\hline & Shibeye & 0.08 & - & - & - & 3.6 & 0.08 & - & - & - & - & - & 6.8 & - & - \\
\hline & Rosterman & 0.06 & - & 11.6 & - & - & - & - & 1.20 & - & - & 4.80 & - & - & - \\
\hline & Mwibatsiro & 6.60 & - & - & - & - & - & - & 1.10 & - & - & 4.72 & - & - & - \\
\hline & MMUST stream & 38.4 & - & - & - & - & - & - & 0.72 & - & - & - & - & - & - \\
\hline
\end{tabular}

- means method detection limit (<MDL). Naphthalene (Nap), Acenaphthylene (Acy), Acenaphthene (Ace), Fluorene (Flu), Phenanthrene (Phe), Anthracene (Ant), Flourancene (Flr), Pyrene (pyr), Benz(a)anthracene (BaA), Chrysene (Chr), Benz(b)flourancene (BbF), Benz(a)pyrene (BaP), Indeno(123,cd)pyrene (InP), Dibenzo(def,mno)chrysene (DBC). 
The ratios of concentrations of PAHs from sugarcane processes samples to those of water and sediment samples in the vicinity of the processing companies indicated a diffuse source of the PAHs rather than specific point source.

The concentration obtained for naphthalene (Nap), Fluorene (Flu), Anthracene (Ant), Chrysene (Chr), Benz(b)flourancene (BbF), Benz(a)pyrene (BaP), Indeno(123,cd)pyrene (InP), Dibenzo(def,mno)chrysene (DBC) ranged as follows; 4.50 - $19.60 \mu \mathrm{g} / \mathrm{kg}, 0.94-14.0 \mu \mathrm{g} / \mathrm{kg}, 6.0-80.0 \mu \mathrm{g} / \mathrm{kg}, 0.14-4.0 \mu \mathrm{g} / \mathrm{kg}, 0.12$ $\mu \mathrm{g} / \mathrm{kg}, 0.14-4.0 \mu \mathrm{g} / \mathrm{kg}$ in all sampling locations respectively. Sediments obtained from Ekero had the highest concentrations of Ant $(80.0 \mu \mathrm{g} / \mathrm{kg})$ and contained five PAHs analysed. Ekero location has intense sugarcane and maize farming. Nap was present in all water samples analysed with the highest concentration of $15.60 \mu \mathrm{g} / \mathrm{L}$. The Mumias sugar company stream carries effluent from and around the sugar factory vicinity. The results indicated that surface runoff from the factory farms and waste from the sugar cane processing may be contributing to the presence of the PAHs observed in this sampling location.

Samples of waste and by products from three sugar processing factories namely Nzoia sugar company (NSC) and West Kenya sugar company (WKSC) were analysed for the PAHs. Bagasse waste samples from NSC had concentrations of Nap, Acy, Flu, Ant and InP ranging from 0.4 to $14 \mu \mathrm{g} / \mathrm{kg}$, while filter cake from the same factory had concentrations of Nap, Phe, Ant, Flr, Inp and DBC ranging from 1.7 to $14 \mu \mathrm{g} / \mathrm{kg}$ (see Table 4). Comparing the two companies, bagasse waste from WKSC had only Nap quantified with a concentration of 2.0 $\mu \mathrm{g} / \mathrm{kg}$. However, the filter cake sample from WKSC had quantifiable levels of Flu, Phe, Ant, Flr, InP and DBC in the concentration range of 5.2 to $30.0 \mu \mathrm{g} / \mathrm{kg}$. The variation of PAHs concentrations in waste and by products from sugar manufacturing processes is related to the kind and conditions of the processes. The same conclusion can be made from the concentrations of PAHs obtained in boiler water in NSC and WKSC where Pyr, BbF, InP, DBC and Nap, Ant, Pyr, $\mathrm{BaA}$ were quantified respectively. Table 4 shows the concentrations of PAHs obtained from sugarcane process waste from NSC and WKSC. Previous studies have indicated that milling process can course contamination [11] along the process hence leading to PAHs introduction to the process.

Table 4. Concentrations of PAHs in different sugar process by products and wastes analysed. Concentration in solid waste is in $\mu \mathrm{g} / \mathrm{kg}$ and water in $\mu \mathrm{g} / \mathrm{L}$.

\begin{tabular}{|c|c|c|c|c|c|c|c|c|c|c|c|c|c|c|}
\hline Matrices & Nap & Acy & Ace & Flu & Phe & Ant & Flr & Pyr & $\mathrm{BaA}$ & Chry & $\mathrm{BbF}$ & $\mathrm{BaP}$ & InP & $\mathrm{DBC}$ \\
\hline Bagasse waste NSC & 12.0 & 8.0 & - & 0.60 & - & 14.0 & - & - & - & - & - & - & 0.4 & - \\
\hline Bagasse waste WKSC & 2.0 & - & - & - & - & - & - & - & - & - & - & - & - & - \\
\hline Filter cake WKSC & - & - & - & 30.0 & 5.20 & 14 & 7.0 & - & - & - & - & - & 30.0 & 28.0 \\
\hline Filter cake NSC & 1.80 & - & - & - & 3.20 & 8.0 & 14.0 & - & - & - & - & - & 1.7 & 12.0 \\
\hline Boiler water NSC & - & - & - & - & - & - & - & 1.20 & - & - & 0.12 & - & 0.12 & 0.08 \\
\hline Boiler water WKSC & 0.07 & - & - & - & - & 0.10 & - & 1.28 & 12.0 & - & - & - & - & - \\
\hline
\end{tabular}

Naphthalene (Nap), Acenaphthylene (Acy), Acenaphthene (Ace), Fluorene (Flu), Phenanthrene (Phe), Anthracene (Ant), Flourancene (Flr), Pyrene (Pyr), Benz(a)anthracene (BaA), Chrysene (Chr), Benz(b)flourancene (BbF), Benz(a)pyrene (BaP), Indeno(123,cd)pyrene (InP), Dibenzo(def,mno)chrysene (DBC). Means below limit of detection $(<\mathrm{MDL})$. 
Various industrial manufacturing processes may induce the generation of PAHs. For example, [30] assessed the contamination of rapeseed oil by PAHs in processes that require temperature control. In the study, it was reported that Benzo[a]pyrene, Benzo[a]fluoranthene, Benzo[b]fluoranthene and chrysene determined in rapeseeds as a result of processing. [31] reported the presence of 16 PAHs in fresh tea leaves due to manufacturing process. In the study, Benzo(a)pyrene which is classified as a $2 \mathrm{~A}$ class carcinogen was found in the dried tea leaves only whereas, naphthalene which is classified as a $2 \mathrm{~B}$ probable human carcinogen was present during all the stages of manufacturing.

\subsection{Distribution of PAHs in Different Sample Matrices in the River Nzoia Catchment Area}

The distribution of PAHs varied among the sampling locations and the sample matrices. There was no single sample where all the priority PAHs were detected. Variation in concentrations indicated different sources of PAHs [32]. The observed concentrations distribution in the Nzoia catchment region, indicates varied sources of the studied PAHs. Figure 2 shows the distribution in percentage
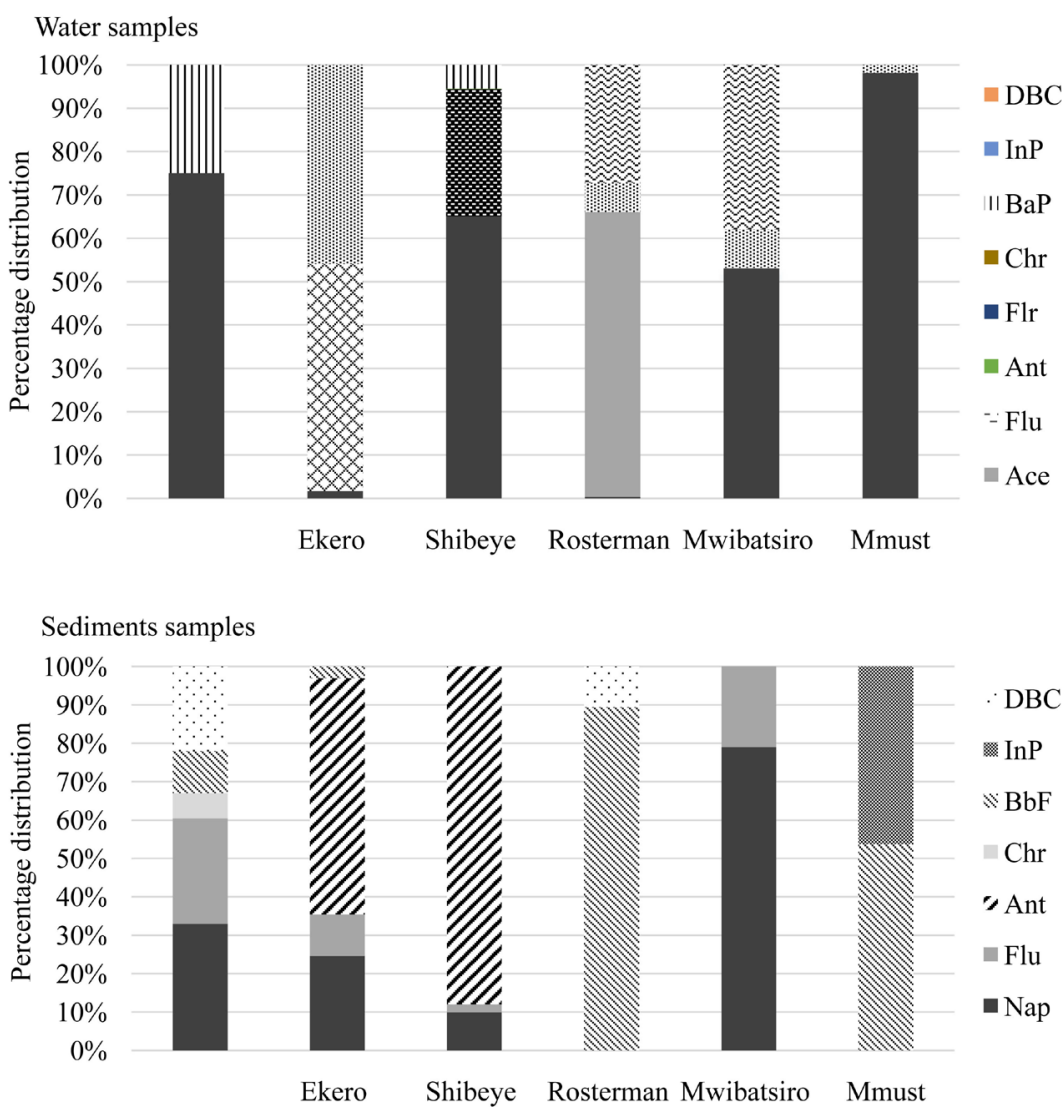

Figure 2. Percentage (\%) of distributions of PAHs contribution in water and sediment samples within the study locations. Naphthalene (Nap), Acenaphthylene (Acy), Acenaphthene (Ace), Fluorene (Flu), Phenanthrene (Phe), Anthracene (Ant), Flourancene (Flr), Pyrene (Pyr), Benz(a)anthracene (BaA), Chrysene (Chr), Benz(b)flourancene (BbF), Benz(a)pyrene (BaP), Indeno(123,cd)pyrene (InP), Dibenzo(def,mno)chrysene (DBC). 
(\%) of PAHs in water and sediments samples. Mumias sugar company stream sample had only two PAHs present with Nap distribution in the sample at over $75 \%$. Ekero, Shibeye, Mwibatsiro and Rosterman which are located along Isiukhu river had at least three PAHs in the water samples.

However, Acy, Nap and Ace make up to more than $50 \%$ of total PAHs in water of the three locations respectively. Benz(a)anthracene $(\mathrm{BaA})$ is dominat in water sample from MMUST stream (over 90\%) and Mwibatsiro (Over 50\%) (see Figure 2). In a study by [33] that $\mathrm{BaA}$ was among the PAHs that showed a good correlation indicating that they originate from the burning processes. Classification of PAHs is based on molecular weights (MW). The classes of PAHs strongly correlate with their environmental fate. Lower molecular weight is PAHs of 152 to $178 \mathrm{~g} / \mathrm{mol}$. The medium (middle) molecular weight PAHs, have about 202 $\mathrm{g} / \mathrm{mol}$ and High Molecular weights have MW of 228 to $278 \mathrm{~g} / \mathrm{mol}$. Predominance of low and medium molecular weight PAHs in water and sediment samples reflected a similar source. The high MW class of PAHs has low solubility in water. These could explain the observed low or/and below method detection limit concentrations of $\mathrm{BaA}, \mathrm{Char}, \mathrm{BbF}, \mathrm{BaP}, \mathrm{InP}$ and $\mathrm{DBC}$ in water samples. The possible contributors of PAHs determined in sediment samples might be through surface runoffs from wastes dumping sites along the river banks. Discharge sewage effluents from the sewerage plant may be contributing significantly to Nap and Flu present in the Mwibatsiro sediments. High hydrophobicity of PAHs is associated with their adsorption on sediments, organic matter and suspended particles [34]. Naphthalene and Phenanthrene are degraded rapidly in sediments but higher MW PAHs such as Benzo(a)pyrene are more recalcitrant [35].

Soils are likely to retain high MW PAHs. The EPA has classified Benz(a)anthracene $(\mathrm{BaA})$, Benz(a)pyrene $(\mathrm{BaP})$, Benz(b)flourancene $(\mathrm{BbF})$, chrysene (Chr), Dibenz(ah)anthracene, and Indeno(1,2,3-cd)pyrene (InP), as probable human carcinogens [7]. Of these carcinogenic PAHs, Benz(a)pyrene (BaP), Benz(b)flourancene (BbF) and Indeno(123,cd)pyrene (InP), were major contributors to the river water and sludge soil. This observation is of major concern since water from the rivers within the study region is abstracted for domestic use. Also, the sludge soil is used as fertilizer in agricultural farms (Figure 3). Show the percentage of distributions of individual PAHs in soil samples obtained from different localities within the Nzoia River catchment area. Naphthalene (Nap), was distributed in all soil samples except the sludge soil sample. It was higher in the MMUST sample (60\% distributed). The MMUST soil sample also contained Indeno(123,cd)pyrene (InP), which tends to adsorption strong onto the soil organic matter. Anthracene recorded the highest concentration of $20 \mu \mathrm{g} / \mathrm{kg}$ and fluorine with the least concentration level of $0.8 \mu \mathrm{g} / \mathrm{kg}$ in Mumias nuclear farm. Observed concentrations of PAHs at this sampling location can be attributed to agricultural activities such as cane farming within the study area is associated with cane burning, during land preparation for another crop. At the 


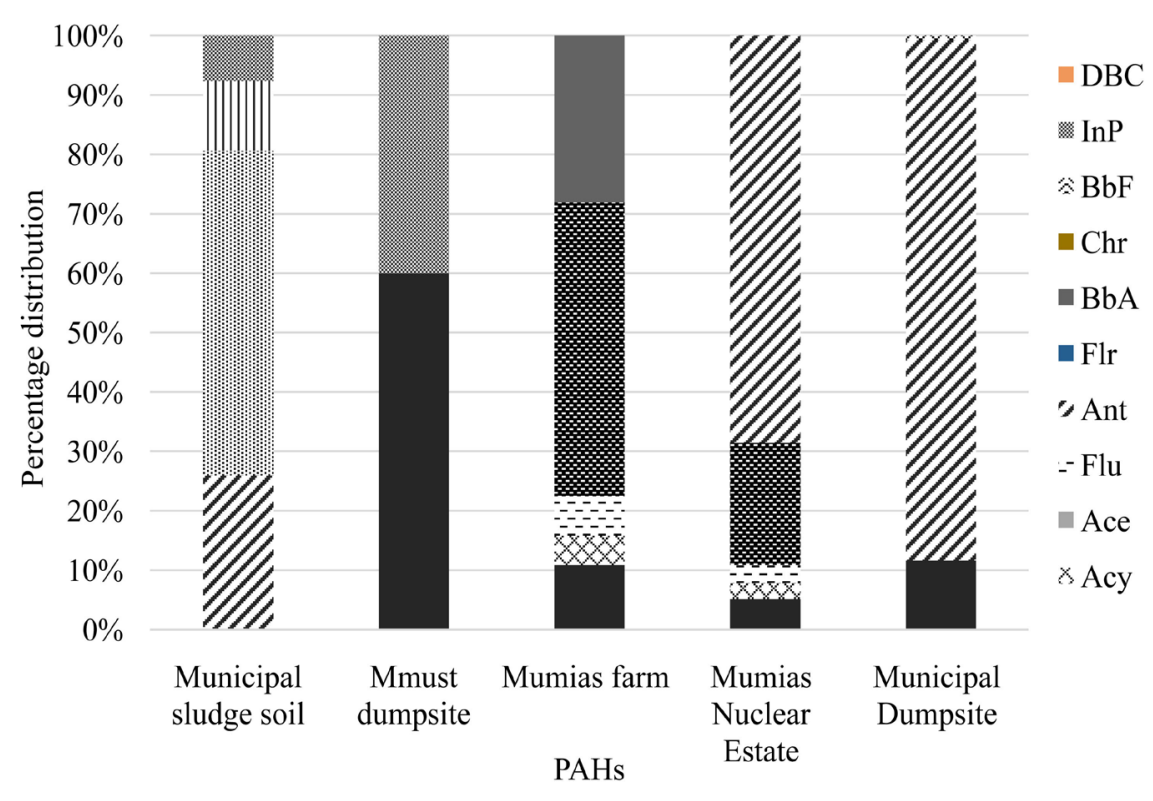

Figure 3. Percentage (\%) of distributions of PAHs contribution in soil samples within the study locations.

Kakamega municipal dumpsite, the high concentration of anthracene of 1200 $\mu \mathrm{g} / \mathrm{kg}$ and Benzo(b)flourancene may therefore be as a result of open burning, which was the observed method used to reduce the waste volumes at dumpsites within the study region. The distribution of anthracene in soil samples was over $85 \%, 65 \%$ and $25 \%$ in municipal dumpsite, mumias nuclear estate and municipal sludge soil samples respectively (see Figure 3). Anthracene is to be one of the most prevalent PAHs in soils in the study region. PAHs are generated by incomplete combustion, thermal means such as fires and burning or by other anthropogenic sources [36] [37]. Higher concentrations of PAHs in urban soils than in rural soils is a clear indicator of urban centers associated anthropogenic activities contribution of PAHs in the environment.

Anthracene was quantified at the municipal dumpsite but not in water and sediment within the dumpsite area. This observation indicated a diffuse source of anthracene. Naphthalene with a concentration of $0.06 \mu \mathrm{g} / \mathrm{L}$ and $160 \mu \mathrm{g} / \mathrm{kg}$ within the vicinity of munipal dumpsite at Rosterman could indicate that the source of naphthalene in water was the municipal dumpsite because of the ratio of 160:0.06 for the dumpsite and water respectively. However concentration of naphthalene at MMUST dumpsite was $6.0 \mu \mathrm{g} / \mathrm{kg}$ and was lower than the concentration obtained in water within the same vicinity which was $38.4 \mu \mathrm{g} / \mathrm{L}$ (ratio of 0.06:38.4) an indication of other various sources of naphthalene in water.

Decomposition of waste at dumpsites, other pyrogenic processes and open burning that take place at the municipal dumpsite may produce and/or release PAHs to the soil. Phenanthrene was distributed in about $50 \%$ of the mumias nuclear estate farm and about $20 \%$ of the soils from municipal dumpsite respectively, even though phenanthrene is espected to be removed from soils due to its relatively high water solubility. 


\subsection{Some International Data on Concentrations of PAHs in Various Matrices}

Polycyclic aromatic hydrocarbons are ubiquitous in the modern environment [38]. Results from around the globe from various researchers generally show a variation in concentrations of PAHs among countries, and sampling locations. [21] researched on PAHs in water and sediments of car wash and kisat areas of winam Golf of Lake Victoria in Kenya. The PAH concentrations in sediment and water ranged from 0.04 to $31.95 \mu \mathrm{g} / \mathrm{kg}$ dry weight and 3.32 to $55.8 \mu \mathrm{g} / \mathrm{L}$, respectively, depending upon the sampling location. [39] studied the distributions of PAHs in surface waters, sediments and soils of Hangzhou city, China and reported that the total concentrations of 10 PAHs in water ranging from 0.989 $\mu \mathrm{g} / \mathrm{L}$ to $9.663 \mu \mathrm{g} / \mathrm{L}$, with a mean concentration of $3.717 \mu \mathrm{g} / \mathrm{L}$. The composition pattern of PAHs in the water showed that PAHs (naphthalene, fluorene, phenanthrene, and pyrene) were the most abundant in all water samples. Five-ring PAHs Benzo(a)anthracene, Benzo(b)fluoranthene, chrysene, and Benzo(a)pyrene concentrations gave the lowest concentrations. Additionally, another study reported in Niger Delta, Nigeria where PAHs concentrations were averaged at $0.1761 \mathrm{mg} / \mathrm{L}$ was determined in selected water bodies in Niger Delta and 1.95 $\mu \mathrm{g} / \mathrm{L}$ to $10.9 \mu \mathrm{g} / \mathrm{L}$ determined in Ekpan Creek [40]. In Ghana, total PAHs reported their concentration range up to $14.587 \mu \mathrm{g} / \mathrm{L}$ [41]. Another study by [42] from China reported that areas with intense navigation and large industrial facilities including oil refineries had higher concentration of PAHs in sediments. In the study, the range of PAHs in concentration obtained ranged from 464 to $2.62 \mu \mathrm{g} / \mathrm{kg}$ as shown in Table 5 .

Study done in China reported PAHs levels from $0.016 \mu \mathrm{g} / \mathrm{kg}$ in rural to 3.884 $\mu \mathrm{g} / \mathrm{kg}$ in the suburban soils of Beijing, China [43]. These levels are higher than those obtained from this study. According to [44] observed that industrial sites had higher PAHs levels than other more remote regions studied. Range in concentrations of PAHs determined by Oketola and [45], in the leachate samples in Lagos Nigeria was 0.85 to $1.47 \mathrm{mg} / \mathrm{L}$ and for top soil around the dumpsite, the values $0.94-2.79 \mathrm{mg} / \mathrm{kg}$. Poor management of dumpsites can cause the leaching of leachate to ground water and surface water through run-off, and can have adverse effects on human health and the ecosystem. [46] obtained high concentrations of total PAHs, inside the landfill $\left(1475 \mu \mathrm{g} \cdot \mathrm{kg}^{-1} \mathrm{dw}\right)$, whereas concentrations in the surrounding soils were by far lower ranging between $11.2-28.1 \mu \mathrm{g} \cdot \mathrm{kg}^{-1}$ $\mathrm{dw}$ for PAHs.

\section{Conclusions and Recommendations}

The environmental levels, sources and distribution of the sixteen priority PAHs were reported for the first time within the different matrices in the Nzoia River catchment area. Sewerage system could also be a potential pathway of PAHs to the environment. Results of PAHs concentrations in sludge soils that originate from the wastewater treatment plant within Kakamega town (the municipal 
Table 5. International data on concentrations of PAHs in various matrices studied, compared to data from this study.

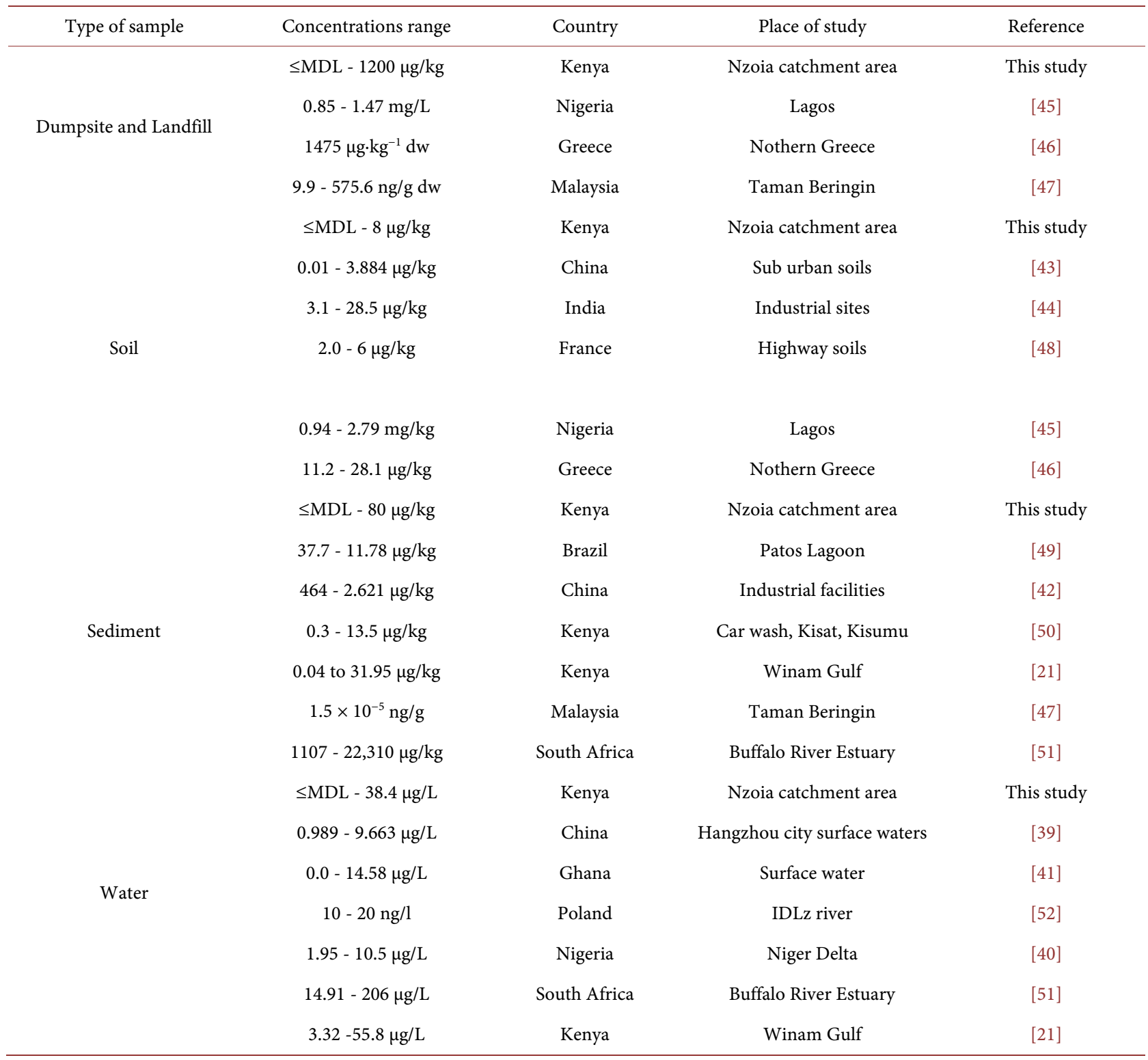

sludge soil sample) had Ant, Pyr, $\mathrm{BaP}$ and $\mathrm{InP}$ in the range of $1.12-8.0 \mu \mathrm{g} / \mathrm{kg}$. This observation indicated that poor waste management contributes significantly to the introduction of PAHs to the respective segments of the environment. Filter cake, bagasse and boiler water samples obtained from two sugar industries contained PAHs. Surface runoff from the factory farms and waste from the sugar cane processing processes may be contributing to the presence of the PAHs. This study recommends the use of cleaner operational conditions by sugar companies, and routine analysis of waste and by products from the processes geared towards eradication of emission and contamination through the processes. Results from these study point towards a variety of sources of PAHs, which can be biomass burning during land preparation, waste reduction by burning at waste dumpsites, and the numerous anthropogenic activities within the urban settle- 
ments within the Nzoia River catchment area. The predominance of low and medium molecular weight PAHs in water and sediment samples was observed, which can be attributed to the low solubility of the higher MW class PAHs. High hydrophobicity of PAHs is also associated with their presence on sediments and suspended particles. Potential carcinogenic PAHs such as Benz(a)pyrene (BaP), Benz(b)flourancene $(\mathrm{BbF})$ and Indeno(123,cd)pyrene (InP) were quantified in river water and sludge soil, which is a major pathway of these compounds to aquatic organisms and human. Mitigation measures that are informed by routine analysis of soil and water samples to identify if there are hotspots soursces of PAHs within the catchment are recommended.

\section{Acknowledgements}

I acknowledge the Masinde Muliro University of science and technology for funding this work through the University Research Finds (URF), Dr. Vincent Madadi and the research group at the University of Nairobi, where sample analysis was made possible using the GC-MS machine.

\section{Conflicts of Interest}

The authors declare no conflicts of interest regarding the publication of this paper.

\section{References}

[1] Fetzer, J.C. (2000) The Chemistry and Analysis of the Large Polycyclic Aromatic Hydrocarbon. Polycyclic Aromatic Compound, 27, 143-162. https://doi.org/10.1080/10406630701268255

[2] Sharma, H., Jain, V.K. and Khan, Z.H. (2007) Characteristics and Source Identification of Polycyclic Aromatic Hydrocarbon (PAHs) in the Urban Environment of Delhi. Chemosphere, 66, 302-310.

https://doi.org/10.1016/j.chemosphere.2006.05.003

[3] Xue, W.-L. and Warshawsky, A. (2005) Metabolic Activation of Polycyclic and Hetero-Cyclic Aromatic Hydrocarbons and DNA Damage: A Review. Toxicology and Applied Pharmacology, 206, 73-93. https://doi.org/10.1016/j.taap.2004.11.006

[4] Hawthorne, S.B., Grabanski, C.B. and Miller, D.J. (2006) Measured Partitioning Coefficients for Parent and Alkyl Polycyclic Aromatic Hydrocarbons in 114 Historically Contaminated Sediments: Part $1 . \mathrm{K}_{\mathrm{oc}}$ Values. Environmental Toxicology and Chemistry, 25, 2901-2911. https://doi.org/10.1897/06-115R.1

[5] Muendo, M., Hanai, Y., Kameda, Y. and Masunaga, S. (2006) Polycyclic Aromatic Hydrocarbons in Urban Air: Concentration Levels, Patterns, and Source Analysis in Nairobi, Kenya. Environmental Forensics, 7, 147-157. https://doi.org/10.1080/15275920600667112

[6] Tobiszewski, M. and Namieśnik, J. (2012) PAH Diagnostic Ratios for the Identification of Pollution Emission sources. Environmental Pollution, 162, 110-119. https://doi.org/10.1016/j.envpol.2011.10.025

[7] US EPA (Environmental Protection Agency) (2008) Polycyclic Aromatic Hydrocarbons (PAHs)_EPA Fact Sheet. National Center for Environmental Assessment, Office of Research and Development, Washington DC. 
[8] European Commission, Scientific Committee on Food (2002) Polycyclic Aromatic Hydrocarbons Occurrence in Foods, Dietary Exposure and Health Effects. http://ec.europa.eu/food/fs/sc/scf/out154_en.pdf

[9] Cordenunsi, B.R., Genovese, M.I. and do Nascimento, J.R.O. (2005) Effects of Temperature on the Chemical Composition and Antioxidant Activity of Three Strawberry Cultivars. Food Chemistry, 91, 113-121. https://doi.org/10.1016/j.foodchem.2004.05.054

[10] Tfouni, S.A.V., Machado, R.M.D., Camargo, M.C.R., Vitorino, S.H.P., Vicente, E. and Toledo, M.C.F. (2007) Determination of Polycyclic Aromatic Hydrocarbons in Cachaça by HPLC with Fluorescence Detection. Food Chemistry, 101, 334-338. https://doi.org/10.1016/j.foodchem.2006.01.040

[11] Camargo, M.C.R. and Toledo, M.C.F. (2002) Polycyclic Aromatic Hydrocarbon Contamination in Different Commodity Groups. Brazilian Journal of Food Technology, 5, 19-26.

[12] Qiao, M., Wang, C., Huang, S., Wang, D. and Wang, Z. (2006) Composition, Sources, and Potential Toxicological Significance of PAHs in the Surface Sediments of the Meiliang Bay, Taihu Lake, China. Environment International, 32, 28-33. https://doi.org/10.1016/j.envint.2005.04.005

[13] Tehrani, R., Hshim, A.H., Sulaiman, S.S.B. and Tavakoly, A. (2012) Distribution of Total Petroleum Hydrocarbons and Polycyclic Aromatic Hydrocarbons in Musa Bay Sediments (Northwest of the Persian Gulf). Environment Protection Engineering, 1, 115-128.

[14] Li, Y.-T., Li, B.-F., Chen, J.-J., Yang, G.-Y., Wan, H.-F. and Zhang, T.-B. (2008) The Concentrations, Distribution and Sources of PAHs in Agricultural Soils and Vegetables from Shunde, Guangdong, China. Environmental Monitoring and Assessment, 139, 61-76. https://doi.org/10.1007/s10661-007-9816-x

[15] Zhang, S., Zhang, Q., Darisaw, S., Ehie, O. and Wang, G. (2007) Simultaneous Quantification of Polycyclic Aromatic Hydrocarbons (PAHs), Polychlorinated Biphenyls (PCBs), and Pharmaceuticals and Personal Care Products (PPCPs) in Mississippi River Water, in New Orleans, Louisiana, USA. Chemosphere, 66, 1057-1069. https://doi.org/10.1016/j.chemosphere.2006.06.067

[16] Zhang, Y.-X. and Tao, S. (2009) Global Atmospheric Emission Inventory of Polycyclic Aromatic Hydrocarbon (PAHs). Atmospheric Environment, 43, 812-819. https://doi.org/10.1016/j.atmosenv.2008.10.050

[17] Tang, L.-L., Tang, X.-Y., Zhu, Y.-G., Zheng, M.-H. and Miao, Q.-L. (2005) Contamination of Polycyclic Aromatic Hydrocarbons (PAHs) in Urban Soils in Beijing, China. Environmental International, 31, 822-828. https://doi.org/10.1016/j.envint.2005.05.031

[18] Wang, Z., Chen, J.-W., Qiao, X.-L., Yang, P., Huang, L. and Tian, F.-L. (2007) Distribution and Sources of Polycyclic Aromatic Hydrocarbons from Urban to Rural Soils: A Case Study in Dalian, China. Chemosphere, 68, 965-971.

https://doi.org/10.1016/j.chemosphere.2007.01.017

[19] Onyango, A.A., Lalah, J.O. and Wandiga, S.O. (2012) The Effect of Local Cooking Methods on Polycyclic Aromatic Hydrocarbons (PAHs) Contents in Beef, Goat Meat, and Pork as Potential Sources of Human Exposure in Kisumu City, Kenya. Polycyclic Aromatic Compounds, 32, 656-668. https://doi.org/10.1080/10406638.2012.725195

[20] Onyango, A.A., Lalah, J.O., Wandiga, S.O. and Gichuki, J. (2012) Assessment of Polycyclic Aromatic Hydrocarbons in Lates niloticus, Oreochromis niloticus and 
Rastrineobola argentea as Sources of Human Exposure in Kisumu Bay, Winam Gulf of Lake Victoria. Bulletin of Environmental Contamination and Toxicology, 88, 747-751. https://doi.org/10.1007/s00128-012-0567-1

[21] Kwach, B.O. and Lalah, J.O. (2009) High Concentrations of Polycyclic Aromatic Hydrocarbons Found in Water and Sediments of Car Wash and Kisat Areas of Winam Gulf, Lake Victoria-Kenya. Bulletin of Environmental Contamination and Toxicology, 83, 727-733. https://doi.org/10.1007/s00128-009-9859-5

[22] Kwach, B.O., Lalah, J.O. and Shem, W.O. (2009) Spatial and Seasonal Variations in Concentrations of Polycyclic Aromatic Hydrocarbons in Water and Sediment of Kisumu City Bay of Winam Gulf, Lake Victoria-Kenya. Bulletin of Environmental Contamination and Toxicology, 83, 734-741.

https://doi.org/10.1007/s00128-009-9830-5

[23] Wanjeri, V.O., Okuku, E.O., Ohowa, B.O., Kosore, M.C. and Ongore, C.O. (2013) An Insight into Ecotoxicological Significance of PAHs Contamination in Selected Kenyan Estuaries. Journal of Environmental Science and Water Resources, 2, 157-166.

[24] Lisouza, F.A., Okinda, P.O. and Lalah, J.O. (2012) Environmental fate of Polycyclic Aromatic Hydrocarbons Emitted from Indoor Burning of Fuel Biomass in Poorly Ventilated Households: A Case Study in the Traditional Rural Households in Western Kenya. In: Bandeira, G.C. and Menezes, H.E., Eds., Polycyclic Aromatic Hydrocarbons. Chemistry, Occurrence and Health Issues, Nova Science Publishers Inc., Hauppauge, New York.

[25] Okoro, D. and Albert, I.O. (2007) Spatial Variation and Distribution of Polycyclic Aromatic Hydrocarbons in Soil. Bulletin of the Chemical Society of Ethiopia, 21, 331-340.

[26] USEPA-Environmental Protection Agency (1996) Test Methods Online USEPA 3540C: Soxhlet Extraction.

[27] Pakpahan E.N., Isa, M.H. and Kutty, S.R.M. (2011) Polycyclic Aromatic Hydrocarbons in Petroleum Sludge Cake: Extraction and Origin-A Case Study. International Journal of Applied Science and Technology, 1, 201-207.

[28] Liang, L., Song, X., Kong, J., Shen, C., Huang, T. and Hu, Z. (2014) Anaerobic Biodegradation of High-Molecular-Weight Polycyclic Aromatic Hydrocarbons by a Facultative Anaerobe Pseudomonas sp. JP1. Biodegradation, 25, 825-833. https://doi.org/10.1007/s10532-014-9702-5

[29] Oleszczuk, P. (2006) Persistence of Polycyclic Aromatic Hydrocarbons (PAHs) in Sewage Sludge-Amended Soil. Chemosphere, 65, 1616-1626. https://doi.org/10.1016/j.chemosphere.2006.03.007

[30] Liu, R., Zhang, Y., Wang, J., Pan, Q., Luo, Y., Sun, Y., Jin, Q. and Wang, X. (2018) Assessment of Contamination Source and Quality Control Approach for Polycyclic Aromatic Hydrocarbons in Wood-Pressed Rapeseed Oil. Food Additives \& Contaminants. Part A, 35, 1155-1163. https://doi.org/10.1080/19440049.2018.1451000

[31] Grover, L.S., Singh, S.A. and Pal. B. (2013) Priority PAHs in Orthodox Black Tea during Manufacturing Process. Environmental Monitoring and Assessment, 185, 6291-6294. https://doi.org/10.1007/s10661-012-3025-y

[32] Maskaouia, K., Zhoub, L., Honga, H. and Zhanga, Z. (2002) Contamination by Polycyclic Aromatic Hydrocarbons in the Jiulong River Estuary and Western Xiamen Sea, China. Environmental Pollution, 118, 109-122. https://doi.org/10.1016/S0269-7491(01)00208-1

[33] Patel, K.S., Ramteke, S., Naik, Y., Sahu, B.L., Sharma, S., Lintelmann, J. and Matus- 
chek, G. (2015) Contamination of Environment with Polycyclic Aromatic Hydrocarbons in India. Journal of Environmental Protection, 6, 1268-1278. https://doi.org/10.4236/jep.2015.611111

[34] Viguli, J., Verde, J. and Irabien, A. (2002) Environmental Assessment of Polycyclic Aromatic Hydrocarbons (PAHs) in Surface Sediments of the Santander Bay, Northern Spain. Chemosphere, 48, 157-165. https://doi.org/10.1016/S0045-6535(02)00105-4

[35] Obayori, O.S. and Salam, L.B. (2010) Degradation of Polycyclic Aromatic Hydrocarbons: Role of Plasmids. Scientific Research and Essays, 5, 4093-4106.

[36] Grova, N., Feidt, C., Crepineau, C., Laurent, C., Lafargue, P.E., Hachimi, A. and Ruchen, G. (2002) Detection of Polycyclic Aromatic Hydrocarbon Level in Milk Collected Near Potential Contamination Sources. Journal Agricultural and Food Chemistry, 50, 4640-4642. https://doi.org/10.1021/jf0201071

[37] Yang, H.-H., Lee, W.-J., Chem, S.-J. and Lai, S.-O. (1998) PAH Emission from Various Industrial Stacks. Journal of Hazardous Materials, 60, 159-174. https://doi.org/10.1016/S0304-3894(98)00089-2

[38] Abdel-Shafy, H.I. and Mansour, M.S.M. (2016) A Review on Polycyclic Aromatic Hydrocarbons: Source, Environmental Impact, Effect on Human Health and Remediation. Egyptian Journal of Petroleum, 25, 107-123.

https://doi.org/10.1016/j.ejpe.2015.03.011

[39] Chen, B., Xuan, X., Zhu, L., Wang, J., Gao, Y., Yang, K., Shen, X. and Lou, B. (2004) Distributions of Polycyclic Aromatic Hydrocarbons in Surface Waters, Sediments and Soils of Hangzhou City, China. Water Research, 38, 3558-3568.

https://doi.org/10.1016/j.watres.2004.05.013

[40] Anya kora, C. and Herbert, C. (2006) Determination of Polynuclear Aromatic Hydrocarbons (PAHs) in Selected Water Bodies in the Niger Delta. African Journal of Biotechnology, 21, 2024-2031.

[41] Essumang, D., Adokoh, C., Afriyie, J. and Mensah, E. (2009) Source Assessment and Analysis of Polycyclic Aromatic Hydrocarbon in the Oblogo Waste Disposal Sites and Some Water Bodies in and around the Accra Metropolis of Ghana. Journal of Water Resource and Protection, 1, 456-468. https://doi.org/10.4236/jwarp.2009.16055

[42] Medeiros, P.M., Bícego, M.C., et al. (2005) Natural and Anthropogenic Hydrocarbons Inputs Sediments of Patos Lagoon Estuary, Brazil. Environment International, 31, 77-87. https://doi.org/10.1016/j.envint.2004.07.001

[43] Ma, L.-L., Chu, S.-G., Wang, X.-T., Cheng, H.-X. and Liu, X. (2005) Polycyclic Aromatic Hydrocarbons in the Surface Soils from Outskirts of Beijing, China. Chemosphere, 58, 1355-1363. https://doi.org/10.1016/j.chemosphere.2004.09.083

[44] Masih, A. and Taneja, A. (2006) Polycyclic Aromatic Hydrocarbons (PAHs) Concentrations and Related Carcinogenic Potencies in Soil at a Semi-Arid Region of India. Chemosphere, 65, 449-456. https://doi.org/10.1016/j.chemosphere.2006.01.062

[45] Oketola, A.A. and Akpotu, S.O. (2014) Assessment of Solid Waste and Dumpsite Leachate and Topsoil. Chemistry and Ecology, 31, 134-146.

https://doi.org/10.1080/02757540.2014.907280

[46] Chrysikou, L., Gemenetzis, P., Kouras, A., Manoli, E., Terzi, E. and Samara, C. (2008) Distribution of Persistent Organic Pollutants, Polycyclic Aromatic Hydrocarbons and Trace Elements in Soil and Vegetation Following a Large-Scale Landfill fire in Northern Greece. Environment International, 34, 210-225.

https://doi.org/10.1016/j.envint.2007.08.007 
[47] Zakaria, M.P., Geik, K.H., Lee, W.Y. and Hayet, R. (2005) Landfill Leachate as a Source of Polycyclic Aromatic Hydrocarbon (PAHs) to Malaysian Waters. Coastal Marine Science, 29, 116-123.

[48] Bryselbout, C., Pascale, H., Jean, C. and Lichtfouse, E. (2000) Polycyclic Aromatic Hydrocarbons in Highway Plants and Soils. Evidence for a Local Distillation Effect. Analusis, 28, 290-293.

[49] Luz, L.P., de Sousa, E.E.H., Kerstner, T., Caramão, E.B. and Sanches, P.J. (2010) Evaluation of Surface Sediment Contamination by Polycyclic Aromatic Hydrocarbons in Colony Z3-(Patos Lagoon, Brazil). Microchemical Journal, 96, 161-166. https://doi.org/10.1016/j.microc.2010.03.003

[50] Li, G., Xia, X., Yang, Z., Wang, R. and Voulvoulis, N. (2006) Distribution and Sources of Polycyclic Aromatic Hydrocarbons in the Middle and Lower Reaches of the Yellow River, China. Environmental Pollution, 144, 985-993.

https://doi.org/10.1016/j.envpol.2006.01.047

[51] Adeniji, A.O., Okoh, O.O. and Okoh, A.I. (2019) Levels of Polycyclic Aromatic Hydrocarbons in the Water and Sediment of Buffalo River Estuary, South Africa and Their Health Risk Assessment. Archives of Environmental Contamination and Toxicology, 76, 657-669. https://doi.org/10.1007/s00244-019-00617-w

[52] Kabzinski, A., Cyran, J. and Juszczack, R. (2002) Determination of Polycyclic Aromatic Hydrocarbons in Water (Including Drinking Water) of Lodz. Polish Journal of Environmental Studies, 11, 695-706. 